\title{
Karlholm Response
}

\author{
Keith Moxey
}

In "After Contemporary Art: Actualization and Anachrony," Dan Karlholm tangles bravely and thoughtfully with some of the dilemmas confronting the worlds of art criticism and art history in the wake of modernism and the rise of non-Euro-American centers of the production of art. If modernism's dependence on a teleologically-determined idea of time faltered with the rise of forms of artistic production that failed to observe Greenbergian dictates about painting's essential "flatness," the development of global artmaking traditions that bear little relation to the chronological histories of Euro-American art complicated matters even further. Where is art going, and what is its relation to the passage of time? Since chronology, a nineteenth-century creation associated with the synchronization of time zones in the interests of global trade, was transparently identified with the age of colonization and the triumph of capital, how can it deal fairly with histories that lie outside this trajectory?

Karlholm offers us a trenchant critique of important theorists for whom the "end" of Hegelian historicism is also the end of time. Replacing Peter Osborne's "postconceptualism" as the fate of all art since 1989, Karlholm proposes "panconceptualism" a term capable of covering all art of all times and thus one that eliminates the historicist framework on which its history has so often depended. The same term allows him to escape the "eternal present" in which Terry Smith alleges that "contemporary" art currently wallows. Karlholm introduces the word "actualization" (by which he means realization), as a concept to cover the creation of art in all places and all times. By these means he hopes to eliminate the continued use of the adjective "contemporary" as a historicist term of value.

Far from suggesting that history is irrelevant to a consideration of art's past Karlholm hopes that his suggestions will actually draw attention to the ability of works of art to contain their own time. Turning to the phenomenological tradition, he cites Gadamer as an author sensitive to the anachronic potential of works of art. He writes:

we need to both historicize and temporalize artifacts like artworks, revealing, first of all, their historical context which is taken to comprise the entire 
expanding space between its birth and its continued duration and present existence, and second of all, determine its potentially multiple temporalities as both belated and ahead of sequence, for example, as constituted by two or several temporal layers. (p. 45)

This historical perspective would allow the continuing value of a work of "art" to be recognized long after its creation: "where all conventional art history is, in truth, a kind of pre-history, a coming to grips with how the work came about, anachrony is better described as after-history (not to be mistaken for some atemporal featureless posthistory);" and: "The old question of establishing what the work is with reference to what it was no longer works. The new question is to establish what the work is with reference to what it is the process of becoming." (p.45)

Karlholm offers us a vision of the history of art more attuned to the idea of "art" than the historicist idea of "history" that has dominated its trajectory to date. It recognizes the crucial importance of the work's power to escape time as well as to create it. What will a non-historicist "history" of art look like? Can it operate without a dominant idea of chronology to which the chronologies of local times and places can be related? Regardless of how the institutional powers of the discipline and the museum meet the very real temporal problem that confronts them, Karlholm offers us a vision of an art history that is sensitive to Einstein's notion of the space-time continuum. If time and space are inextricably linked, there are more of art histories to tell than have ever been imagined. 


\title{
Training the Imagination
}

\author{
A Praxis of Gayatri Spivak's "Aesthetic Education" Using \\ Arundhati Roy's "The God of Small Things" as a Reading in \\ Philippine Schools
}

\section{Seneca Nuñeza Pellano}

\begin{abstract}
A вStRAct Presented as a "speculative manual on pedagogy," this article seeks to provide praxis to Spivak's Aesthetic Education in the Era of Globalization (2012) using Arundhati Roy's The God of Small Things (1997) as a reading in Philippine schools. Its aim is to envision pedagogical ways in which a foreign literary text is introduced into a culturally distant setting, thereby prompting educators - the "supposed trainers of the mind" - to resolve: (1) How does one educate aesthetically? (2) How do we imagine the performance of aesthetic education in local classrooms? In demonstrating a theory and its form, the paper first explores Spivak's conception of aesthetic education and then adapts it in a specific case: in Philippine classrooms where learners are confronted by a literary work of the Other-particularly, Arundhati Roy's The God of Small Things. Aesthetic education, as a theoretic idea, is visualized and imaginatively performed through its capacity to realize an "epistemic revolution" happening in local classrooms worldwide.

KEYWORDS Aesthetic education, Spivak, Arundhati Roy, Ab-use, Schiller, Training of imagination, Close reading, Double bind
\end{abstract}

\section{Introduction}

I write this speculative manual on pedagogy as I imagine Gayatri Spivak's mantra (or "sacred utterance" in Sanskrit) on aesthetic education. Speculative, for its aim is to play, particularly with theory and practice on aesthetic education - striving to give it shape and to shape it; to form and to perform it in the mind, where learning dwells. Known for her dense and complex prose, Spivak's deliberate concealment of the procedure and form of aesthetic education leaves us - the supposed "trainers of the mind" - to ask: how does one educate aesthetically? If aesthetic education is the last obtainable resource to combat the homogenizing effects of globalization, how does one imagine it being performed in a specific classroom?

At a library here in Denmark, staring at Spivak's An Aesthetic Education in the Era of Globalization laying beside Arundhati Roy's The God of Small Things, I seek to find "aesthetic" ways to teach the Indian novel in another context: in Philippine schools for instance, where I one day aim to teach. The process, as a result, provides a realistic assessment, not only about my understanding of various concepts on aesthetic education, but 